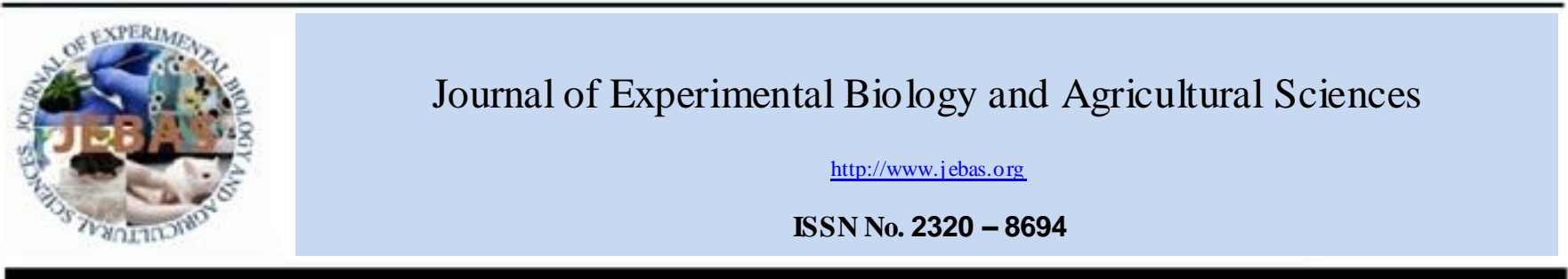

\title{
CHARACTERIZATION OF FARMERS' CROPPING SYSTEMS IN THREE DISTRICTS (BONOU, OUINHI, ZAGNANADO) OF BENIN REPUBLIC
}

\author{
LAW ANI Rebecca Annick Niréti ${ }^{1 *}$, KELOME Nelly Carine ${ }^{2}$, AGASSOUNON DJIKPO TCHIBOZO \\ Micheline $^{3}$, HOUNKPE Jechonias ${ }^{2}$ \\ ${ }^{1}$ University of Abom ey-Cal avi, National Institute of Water, Laboratory of Applied Hydrology (LHA), 01 BP 1950 Abomey -Cal avi (B enin) \\ ${ }^{2}$ University of Abomey-Cal avi, Faculty of Sciences and Techniques, Department of Earth Sciences, Laboratory of Geology, Mines and Environment (LaboGME), \\ BP: 01 BP 526 Cotonou (Benin) \\ ${ }^{3}$ University of Abomey-Calavi, Faculty of Science and Techniques, Department of Genetics and Biotechnology, Laboratory of Standards, Microbiological Quality \\ Control, Nutrition and Pharmacology (LNCQMNP), 01 BP1636 RP Cotonou (Benin)
}

Received - March 05, 2017; Revision - April 24, 2017; Accepted - June 19, 2017 Available

Avail able Online - June 30, 2017

DOI: http://dx.doi.org/10.18006/2017.5(3).321.331

\section{KEYWORDS}

Agricultural Practices

Crops

Fertilizers

Pesticide

Human Health

Benin Republic

\section{ABSTRACT}

Objective of this study was to understand farmer's management practices related to water quality and sanitary issue in order to assess the risks of these practices especially in the Upper Ouémé Delta. All the data related to this investigation were collected by field observations, interviews, surveys of farming households and focus groups. The surveys were conducted with 387 farmers belongs to three districts of southern Benin (Bonou, Ouinhi, and Zagnanado). Results of study revealed that $97.48 \%, 57.78 \%, 76 \%$ of farmers respectively of the Bonou, Ouinhi, and Zagnanado districts grow food crops. Among these, 2.53\%, $42.22 \%$ and $24 \%$ cultivate cash crops such as cotton and oil palm. According to survey results, soil conservation and tillage practices are widely practiced. Further, crops rotation and fallow are widely practiced in all studied districts and $84.84 \%$ of the surveyed farmers use chemical pesticides to maximize crop yields. Among these, only $2.32 \%$ farmers used aqueous extracts of Azaradichta indica leaves for protecting crops against pests. The sources of the environmental risk are the type of chemical product on pesticide used, its toxicity, the parallel circuits of provisioning of pesticides, and the lack of use of protection clothes for spraying these products. This practice allowed ground and water pollution and leads to public health matter. A promotion of good practices is essential for a durable exploitation of the natural resources of the Upper Delta of Ouémé area.

\section{* Correspon ding author}

E-mail: rebecca.lawany @yahoo.fr (LAWANI Rebecca Annick Niréti)

Peer review under responsibility of Journal of Experiment al Biology and Agri cultural Sciences.

Production and Hosting by Horizon Publisher Indi a [HPI] (http://www.hori zon publish erindi a.in/).

All rights reserved.
All the article published by Journal of Experimental Biology and Agricultural Sciences is licensed under a Creative Commons Attribution-Non Commercial 4.0 International License Based on a work at www.jebas.org.

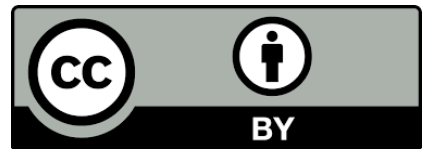




\section{Introduction}

Agriculture employs a large number of assets in the world and especially in the underdeveloped countries. It remains main economic activity in developing countries. This is an activity practiced in a traditional way for family consumption and national self-sufficiency. It is supplemented in some underdeveloped countries by cash crops such as cotton, cocoa, coffee or fruit (Hauchart, 2007). Limited availability of the land and rapid population growth are forcing farmers to increase agricultural productivity to ensure sustainable production. For this, varieties of cultural practices are implemented, but they also have effects on the environment. misuse of pesticides and chemical fertilizers, irrigation, tillage, plant hormone applications, stubble burning, planting without rotation and inappropriate animal wastes are some of the bad cultural practices (Shujaat et al., 2013).

In Benin Republic, agriculture is the main source of cash inflow throughout the country and cash crops are playing much important role (Koudokpon et al., 1994). Its contribution to gross domestic production (GDP) is $36 \%$ and it is achieved by the activity of $3 / 4$ of the active population (Soulé, 2012). It also contributes more than $85 \%$ to official export earnings (Soulé, 2012). Further, climate and soils also favor the diversification of agricultural production and allow production to cover essential basic food needs. However, excessive agricultural activities sometimes, caused damages to the natural resources. Indeed, some agricultural practices used currently, such as slash and burning of agriculture waste, excessive use of chemical inputs and continuous cropping creates environmental issues. People express increasingly growing need to occupy new lands, which results in the destruction of vegetation, declining wildlife and shrinking grazing areas. All these practices expose populations to health hazards (dermatological infections, respiratory infections, etc.) linked to the use of chemical inputs in production areas.

It is therefore necessary to be familiar with the agricultural practices currently being implemented in Benin republic in order to understand their impacts on human health and the environment. Some studies have already been carried out (Soclo, 2003; Yehouenou et al., 2014) to understand the impact of farmers activities or pesticides residues on the groundwater and surface water contamination in cotton growing areas and market gardens, but information related to the upper Delta of Ouémé, a highly agricultural area are not available.

This study has been carried out to provide a better knowledge of different agricultural practices used in the Upper Delta of Ouémé, Benin Republic. Furthers, the study is also conducted to understand the impact of these agricultural practices on the environment and the health of residents. This will help in foresee technological packages for sustainable agriculture in the study area.

\section{Materials and Methods}

\subsection{Study area}

This study covered three districts (Bonou, Ouinhi and Zagnanado) of southern regions of Benin Republic (Figure 1). These districts are characterized by two rainy seasons and two dry seasons of unequal importance. Among this, the district of Zagnanado is located on the plateau of Zagnanado, the smaller trays north depression of LAMA between $7^{\circ}$ to $7^{\circ} 30^{\prime}$ North latitude and $2^{\circ} 15^{\prime}$ to $2^{\circ} 30^{\prime}$ East longitude. It has a total area of 750 square kilometers

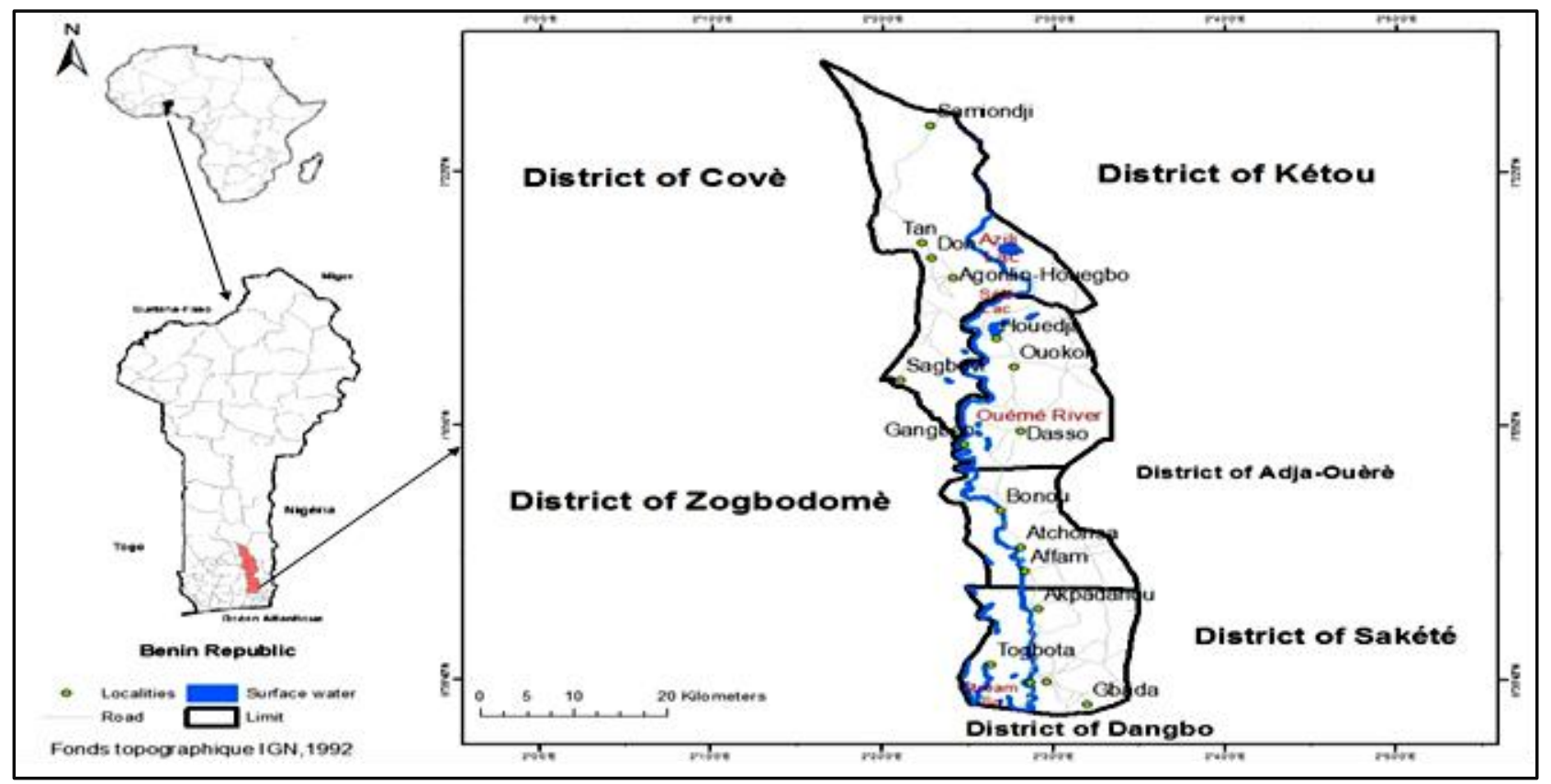

Figure 1 Geographical location of the study area 
$(\mathrm{Km})$ and is bounded to the North by the district of Dassa-Zoumé, South by Ouinhi and Zogbodomey districts, to the East by the districts of Ketou, Adja-Ouèrè and to the West by Covè, ZaKpotaand Djidja. Second district Ouinhi covering an area of total $483 \mathrm{~km}^{2}$, is located between $6^{\circ} 57^{\prime}$ to $7^{\circ} 11^{\prime}$ North latitudes and $2^{\circ}$ 23 ' to $2^{\circ} 33^{\prime}$ East longitudes. It is limited to the northwest by the district of Zagnanado, southwest by the district of Zogbodomey. On the south side, it is limited by the district of Bonou at the east by the district of Adja-Ouèrè. The third and last selected district is Bonou. It is located between $6^{\circ} 72^{\prime}$ to $6^{\circ} 95^{\prime}$ north latitude and $2^{\circ}$ $15^{\prime}$ to $2^{\circ} 40^{\prime}$ East longitude. It is bounded on the North by Ouinhi, South by the Adjohoun, to the East by the districts of Sakété and Adja-Ouèrè and West by those of Zê and Zogbodomè and covers a total area of $250 \mathrm{~km}^{2}$ (INSAE, 2015). All three studied districts have lateritic soils, which favor the cultivation of annual crops (maize, cassava, beans, sweet potatoes and peanuts) as well as perennial (oil palm plantation, teak and acacia).

\subsection{Selection of Respondents}

Surveys were conducted with 387 farmers residing on the study area, from last twenty (20) years because below this age, people do not practice agriculture as a main activity, but as an occasional activity or to help their parents. They do not therefore master all the out lines of agricultural activity. These respondents were chosen randomly as a representative sample of the four ethnic groups (Mahi, Fon, Wémè, and Holli) (Table 1). Surveys were conducted in all the selected areas (Bonou, Zagnanado and Ouinhi) by personal interview. During this, the data were collected using a questionnaire developed and reviewed from the results of the exploratory phase of the study. Questionnaires were based on the

Table 1 Socio-cultural status of the surveyed Districts

\begin{tabular}{|c|c|c|c|c|}
\hline Districts & $\begin{array}{l}\text { Number of } \\
\text { surveyed } \\
\text { respondents }\end{array}$ & Localities & $\begin{array}{c}\text { Percenta } \\
\text { ges by } \\
\text { Localities } \\
(\%)\end{array}$ & $\begin{array}{l}\text { Ethnic } \\
\text { group }\end{array}$ \\
\hline \multirow{5}{*}{ Bonou } & \multirow{5}{*}{131} & Affame & 10.4 & Wémè \\
\hline & & Atchonsa & 4.0 & Wémè \\
\hline & & Dame-Wogon & 0.4 & Wémè \\
\hline & & Houinvigue & 6.5 & Wémè \\
\hline & & Bonou & 4.3 & Wémè \\
\hline \multirow{4}{*}{ Ouinhi } & \multirow{4}{*}{125} & Dasso & 6.8 & Mahi \\
\hline & & Sagon & 15.8 & Fon \\
\hline & & Tohoue & 6.1 & Mahi \\
\hline & & Ouinhi & 14.7 & Mahi, Holli \\
\hline \multirow{4}{*}{$\begin{array}{c}\text { Zagnanad } \\
\text { o }\end{array}$} & \multirow{4}{*}{131} & $\begin{array}{l}\text { Agonli- } \\
\text { Houegbo }\end{array}$ & 1.8 & Mahi \\
\hline & & Dovi & 10.4 & Mahi \\
\hline & & Kpedekpo & 15.1 & Fon, Mahi \\
\hline & & Zagnanado & 3.6 & Fon \\
\hline
\end{tabular}

qualitative factors such as work experience, education level, type of training, crops, farming practices. The farming practices are about clearing, tillage, fertilization, crop rotation, pest management and fallow, application periods and equipment used, supply chains, mode of storage of agricultural inputs, management of empty packaging, the perception of farmers on environmental and health impacts. Results of individual interviews were also supplemented by the interviews conducted with resource persons (CECPA staff, CARDER staff, etc.). Direct observations have focused on different agricultural practices. The size of the sample $(\mathrm{N})$ is obtained using the normal approximation of the binomial distribution according to Dagnelie (1998). The required sample size can be calculated by following formula:

$$
N=\left[(U 1-\alpha / 2)^{2} \times p(1-p)\right] / d^{2}
$$

With $\mathrm{n} \geq 50$ and $\mathrm{p} \geq 1 / 10$ of population, $\mathrm{N}=$ sample size required per village of study; U1- $\alpha / 2=$ confidence level of $95 \%$ (typical value of 1.96); $\mathrm{p}=$ proportion known or suspected in the parent population; $\mathrm{d}=$ margin of error of $5 \%$ (typical value of 0.05 ).

\subsection{Processing and analysis of data}

The data were processed with a spread sheet, Microsoft Excel and analyzed with SPSS (Statistical Package for the Social Sciences) Version 16.0 in order to have a descriptive statistics (percentages, averages, standard errors etc.). The Chi square test was conducted to statistically verify if there is a dependency between agricultural practices and districts and to inform us about the specificity of farming practices in relation to districts studied.

\section{RESULTS}

\subsection{Characteristics of the sampled farmers}

Table 2 shows the profiles of the studied respondents (farmers) in the three districts of Upper Delta Ouémé in Benin. Education and social-demographic characteristics are the two main characteristics of the farmers which are importantly considered in this study. Further, the studied population consists mainly of farmers whose age range is between 30 and 75 years with an average of 43 years. The average age of household heads are reported 40 years in Bonou while it was reported 44 years in Ouinhi and Zagnanado districts (Table 2).

Among the studied field, $77.3 \%$ of the fields are possessed by native people and these have agriculture as their main activity. The number of non-native respondents is very low. Farmers are also involved in the fishing, trade, and hunting. $56.7 \%$ among them are not educated. However, $58.2 \%$ of Zagnanado's farmers are educated as compared to those of Bonou (35.7\%) and Ouinhi districts $(37.1 \%)$. Regarding gender, $92.4 \%$ of respondents were male and $7.6 \%$ were women. This low rate of women farmers is 
explained by the fact that access to land is rather difficult in the study area and that land ownership is not available to female farmers. Women are more specialized in trade, processing of agricultural products and fishing. In case of farming experience, 92. $8 \%$ of the respondents have more than 10 years' experience (Table 2).

\subsection{Important Crops Cultivated in the study area}

The main crops widely cultivated are maize, rice, cowpea, peanuts, cassava, yam, pepper, tomato. As cash crop, farmers usually grow oil palm and cotton. Among the surveyed respondents, 77.2\% produced food crops for their food security while $22.8 \%$ produced cash crop for direct income generation.

\subsection{Farming systems adopted in surveyed districts}

\subsubsection{Agricultural equipment used by study area farmers and soil preparation practices}

The results of the survey revealed that farmers are far from using motorized agricultural equipment and that all the producers use traditional tools that are rudimentary materials made by local craftsmen (hoes, machetes and cans). These rudimentary tools no longer allow users to have a large production, especially when they are elderly. In order to carry out phytosanitary treatment operations, $90.2 \%$ of the farmers surveyed use sprayers while the rest of the farmers use traditional or handmade equipment, such as watering cans, buckets or bottles. Farmers of the surveyed districts (Bonou, Ouinhi and Zagnanado) usually used two (02) types of soil preparation techniques: clearing without burning, and clearing with burning. The technique of burning is usually applied for clearing of new land or land left fallow. It is practiced by $40.6 \%$ of farmers while $59.4 \%$ used land clearing without burning technique. The shifting cultivation is the main cultivation technique which is used by the study area respondents. Depending on the crop (tuber or grain) and soil types (deep, skeletal), farmers used ridges or mounds techniques for sowing. Mounding techniques are used by $33.6 \%$ of respondents, while the rest of the respondents used ridges techniques. Different soil preparation practices are significantly specific in to studied district, clearing and tillage type at the $1 \%$.

\subsubsection{Crop management practices}

Crop rotation, fallow and intercropping (soil conservation practices) are the some crop management practices which were frequently adopted by the farmers of the studied sites. Among these, crops rotation is widely practiced $(45.6 \%)$. The order of crops rotation allows farmers to benefit from back effects of chemical fertilizers, and helps crops to fight against some weeds. Crop rotation is followed by the fallow (36.9\%). These results show that the studied site is under land pressure unlike other
Table 2 Social and demographic characteristics of farmers of all three surveyed districts

\begin{tabular}{|c|c|c|c|c|}
\hline \multirow[t]{2}{*}{ Variables } & \multirow[t]{2}{*}{ Modalities } & \multicolumn{3}{|c|}{ Frequency (\%) } \\
\hline & & Bonou & Ouinhi & Zagnanado \\
\hline \multirow{2}{*}{ Gender } & Male & 95.8 & 94.2 & 87.2 \\
\hline & Female & 4.20 & 5.80 & 12.8 \\
\hline \multirow{4}{*}{ Age } & $30-40$ years & 62.7 & 36.7 & 44.7 \\
\hline & $40-50$ & 28.4 & 40.8 & 40.0 \\
\hline & $50-60$ & 4.50 & 16.7 & 9.40 \\
\hline & $>60$ years & 4.50 & 5.80 & 5.90 \\
\hline \multirow{2}{*}{ Origin } & Native & 85.9 & 72.7 & 76.7 \\
\hline & Immigrants & 14.1 & 14.9 & 5.80 \\
\hline \multirow{4}{*}{$\begin{array}{l}\text { Level of } \\
\text { education }\end{array}$} & Illiterate & 64.3 & 62.8 & 41.9 \\
\hline & Primary level & 24.3 & 22.3 & 44.2 \\
\hline & Secondary level & 11.4 & 14.0 & 14.0 \\
\hline & University level & 0.00 & 0.80 & 0.00 \\
\hline \multirow{2}{*}{$\begin{array}{l}\text { Experience } \\
\text { in agriculture }\end{array}$} & $5-10$ & 4.20 & 5.00 & 8.10 \\
\hline & $>10$ years & 91.5 & 94.2 & 80.2 \\
\hline
\end{tabular}

villages where the pressure is still fair. Intercropping is practiced by $73.2 \%$ of the farmers (Table 3 ) while monoculture is practiced by only $23.29 \%$ of the surveyed farmers. This practice constitutes a genuine threat to food security due to land exhaustion. In the districts concerned, another practice is to divide cultures between

Table 3 Crop management practices followed by the respondents of the study area

\begin{tabular}{|llll|}
\hline \multicolumn{1}{|c}{ Variables } & \multicolumn{3}{c|}{ Frequencies } \\
& Bonou & Ouinhi & Zagnanado \\
\hline Fallow & 37.2 & 45.0 & 27.0 \\
\hline Rotation & 9.00 & 64.2 & 52.0 \\
\hline Crop association & 44.9 & 95.8 & 68.0 \\
\hline Monoculture & 69.2 & 37.5 & 34.0 \\
\hline Crop rotation & 21.8 & 60.0 & 44.0 \\
\hline
\end{tabular}

plots. This practice is done by producers who have a single field, or have a large field in a locality, or those whose lands are adjacent to the banks of rivers. These producers are $44.6 \%$ of the surveyed population.

\subsubsection{Fertilization practices}

Fertilization is a common practice. $33.6 \%$ of the farmers used organic fertilizers (soil conservation practice) while $66.3 \%$ used mineral fertilizers. Among the mineral fertilizers, NPK (15-15-15) and Urea are the most commonly used. In case of organic fertilizer, most of the studied respondents used household garbage, compost and animal wastes. A highly significant relationship was reported between fertilization and studied villages watersheds $(\chi 2=25$. 
412; $\mathrm{p}=0.000)$. So, fertilization is a practice that significantly discriminates the surveyed sites. $10.4 \%$ of the studied farmers used both inorganic and mineral fertilizers. However, during the survey, it was reported that $15.4 \%$ farmers did not use any fertilizer for their crops.

\subsubsection{Crop protection practices}

During the survey, it was reported that all the studied respondents are aware about crop losses due to the attack of pathogen, insect and pest. To combat pests, farmers use curative measures such as herbicides, in secticides and aqueous extracts of plants. Six major classes of chemical pesticides, which are widely used by study area respondents to protect their crop are: organophosphates, organochlorines, carbamates, amino phosphonates glycine, pyridines and Pyrethroids. (Table 4; Figure 4). Among these chemicals, the active ingredients amino phosphonates glycine $(42.8 \%)$ were the most frequently used and it was followed by Pyrethroids (28.5\%), organophosphates (21.4\%), organochlorines (7\%) and carbamates Pyridines (7\%) (Figure 2). The use of prohibited active ingredients was not reported during this survey.

Pesticides are used by $86.5 \%$ of farmers. Insecticides and herbicides are the categories of pesticides used. $23.2 \%$ of farmers used insecticides and $11.8 \%$ used herbicides for weed control. The insecticides are widely used for controlling the infestation of caterpillars, moths, sucking insects, and aphids (Figure 3 ). The herbicides are sprayed on the space occupied by quack grass (Imperata cylindrica). This action asphyxiates the growth of the species and protects the crops. The most commonly used herbicides are Zaki, Paraphos, Glyphogan, Sunsale, Tackle, Total and Force up. Among the surveyed respondents, 48.8 percent respondents used both insecticides and herbicides (Table 5).

Getting pesticides, insecticides and herbicides are also difficult for the study area farmers. During this study, three pesticides supply routes have been identified. Most of the farmers collect these chemicals from the approved agencies such as Communal Agricultural Promotion Center (CeCPA) and private distribution companies while some of the producer purchases these from the local markets. The third supply channel is Nigerian foreign market, which is not far from the three selected districts.

For performing insect pest management, $90.2 \%$ of the surveyed farmers used knapsack sprayer while the rest of the farmers used traditional or handmade equipment such as watering can s, bucket and bottles for spraying (Figure 3 ).
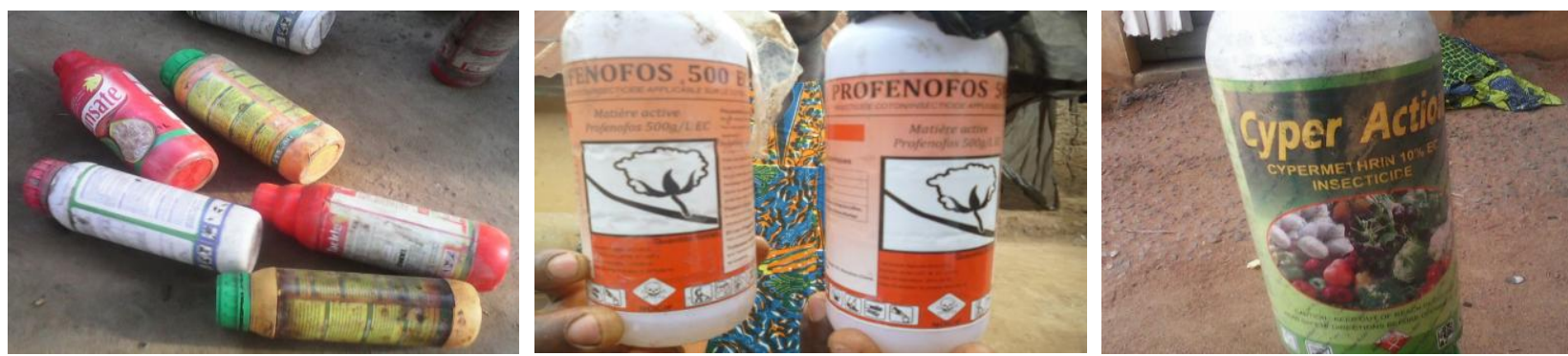

Figure 2 Various pesticides use in Bonou, Zagnanado and Ouinhidistricts
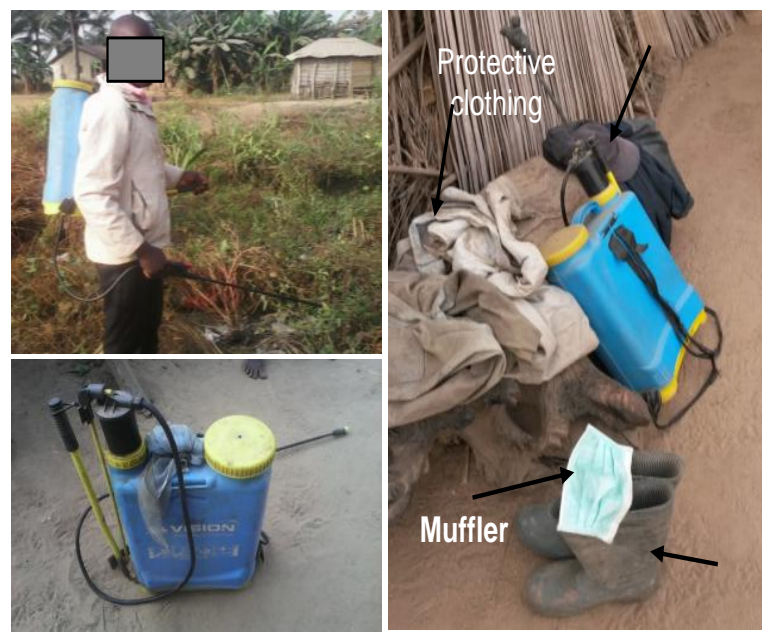

Figure 3 Protective equipment and sprayers used by farmers

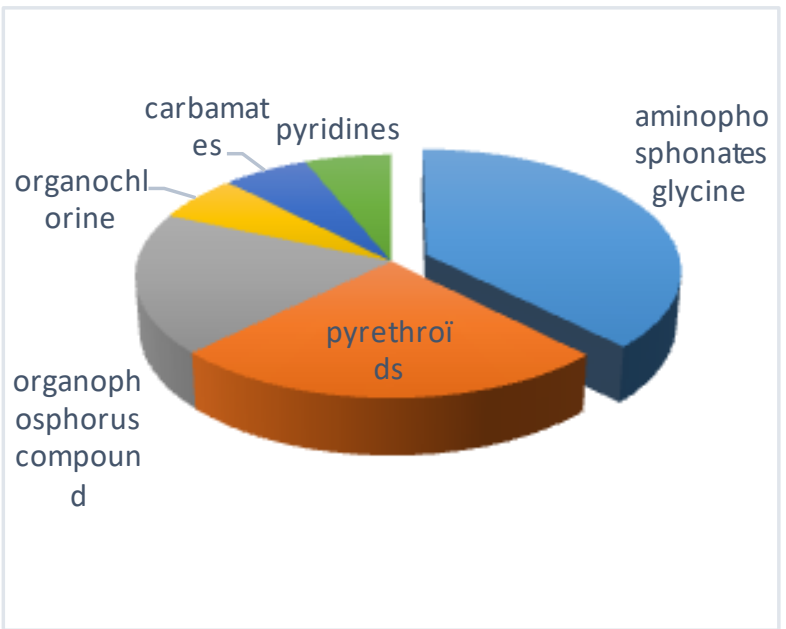

Figure 4 Distribution of active ingredients by chemical family 


\begin{tabular}{|c|c|c|c|c|c|c|c|}
\hline Purpose & Product name & $\begin{array}{l}\text { Composition and } \\
\text { concentration }\end{array}$ & Chemical family & $\begin{array}{l}\text { Chemical } \\
\text { formulas }\end{array}$ & $\begin{array}{c}(\text { WHO }) \\
\text { Hazard class } \\
(\text { WHO, 2009) }\end{array}$ & Origin & Nature \\
\hline \multirow{4}{*}{$\begin{array}{l}\text { Insecticide for } \\
\text { cotton field }\end{array}$} & $\begin{array}{l}\text { Fariapermfos } \\
\quad \text { BC }\end{array}$ & Cypermethrin $10 \%$ & Synthet ic Pyrethroids & $\mathrm{C}_{22} \mathrm{H}_{19} \mathrm{Cl}_{2} \mathrm{NO}_{3}$ & II & $\begin{array}{l}\text { Benin distribution } \\
\text { centers }\end{array}$ & $\begin{array}{l}\text { Is extremely toxic to fish and } \\
\text { freshwater invertebrates }\end{array}$ \\
\hline & Profenofos & Profenofos $500 \mathrm{~g} / 1$ & Organophosphorus compound & $\mathrm{C}_{11} \mathrm{H}_{15} \mathrm{BrClO}_{3} \mathrm{PS}$ & II & $\begin{array}{l}\text { Benin distribution } \\
\text { centers }\end{array}$ & Extremely dangerous \\
\hline & Coton plus & $\begin{array}{l}\text { Cypermethrin } 72 \mathrm{~g} / 1 \\
\text { Acétampiride }\end{array}$ & $\begin{array}{l}\text { Synthet ic Pyrethroids and } \\
\text { Organochlorine compound }\end{array}$ & $\begin{array}{l}\mathrm{C}_{22} \mathrm{H}_{19} \mathrm{Cl}_{2} \mathrm{NO}_{3} \\
\mathrm{C} 10 \mathrm{H} 11 \mathrm{ClN} 4\end{array}$ & & $\begin{array}{l}\text { Benin distribution } \\
\text { centers }\end{array}$ & \multirow[t]{2}{*}{$\begin{array}{l}\text { Is extremely toxic to fish and } \\
\text { freshwater invertebrates }\end{array}$} \\
\hline & Cyper Action & Cypermethrin $10 \%$ & Synthet ic Pyrethroids & $\mathrm{C}_{22} \mathrm{H}_{19} \mathrm{Cl}_{2} \mathrm{NO}_{3}$ & II & Nigeria market & \\
\hline \multirow{2}{*}{$\begin{array}{c}\text { Other } \\
\text { insecticides }\end{array}$} & Lambda Finer & Lambda-cyhalothrine 25 & Synthet ic Pyrethroids & $\mathrm{C}_{23} \mathrm{H}_{19} \mathrm{ClF}_{3} \mathrm{NO}_{3}$ & II & Nigeria market & $\begin{array}{l}\text { Toxic to the aquatic environment } \\
\text { Is extremely toxic to fish and } \\
\text { freshwater invertebrates. } \\
\text { Not registered }\end{array}$ \\
\hline & Aminophos & Méthomyl & Carbamates & $\mathrm{C}_{5} \mathrm{H}_{10} \mathrm{~N}_{2} \mathrm{O}_{2} \mathrm{~S}$ & $\mathrm{Ib}$ & $\begin{array}{l}\text { Benin distribution } \\
\text { centers }\end{array}$ & $\begin{array}{l}\text { Highly toxic in freshwater fish and } \\
\text { extremely toxic in aquatic } \\
\text { invertebrates } \\
\text { High leaching potential }\end{array}$ \\
\hline \multirow{7}{*}{ Herbicide } & Zaki & Paraquat $20 \%$ & Bipyridylium derivative & $\mathrm{C}_{10} \mathrm{H}_{8} \mathrm{~N}_{2}$ & II & Nigeria market & $\begin{array}{l}\text { Very toxic to aquatic life with long } \\
\text { lasting effects } \\
\text { Fatal if inhaled }\end{array}$ \\
\hline & Paraphos & $\begin{array}{l}\text { Chlorofenizon }(20 \%) \\
\text { Parathion-ethyl (10\%) }\end{array}$ & $\begin{array}{c}\text { Sulfonates and } \\
\text { Organophosphorus }\end{array}$ & $\begin{array}{l}\mathrm{C}_{12} \mathrm{H}_{8} \mathrm{Cl}_{2} \mathrm{O}_{3} \mathrm{~S} \\
\mathrm{C}_{10} \mathrm{H}_{14} \mathrm{NO}_{5} \mathrm{PS}\end{array}$ & I a & Nigeria market & $\begin{array}{l}\text { Very toxic to aquatic life with long } \\
\text { lasting effects } \\
\text { Fatal if swallowed }\end{array}$ \\
\hline & Glyphogan & $\begin{array}{l}\text { Glyphosate } 180 \mathrm{~g} / 1 \text { et } \\
\text { terbuthylazine } 345 \mathrm{~g} / 1\end{array}$ & $\begin{array}{l}\text { Aminophosphonates glycine } \\
\text { Organophosphorus compound }\end{array}$ & $\mathrm{C}_{3} \mathrm{H}_{8} \mathrm{NO}_{5} \mathrm{P}$ & III & Nigeria market & \multirow{6}{*}{$\begin{array}{l}\text { Potential low risk } \\
\text { Does not accumulate in fish and } \\
\text { other animals } \\
\text { Rapid degradation }\end{array}$} \\
\hline & Sunsale & $\begin{array}{l}\text { Glyphosate } 360 \mathrm{~g} / \mathrm{l} \\
\text { Glyphosate isopropryl } \\
\text { ammonium } 480 \mathrm{~g} / \mathrm{l}\end{array}$ & Aminophosphonates glycine & $\mathrm{C}_{3} \mathrm{H}_{8} \mathrm{NO}_{5} \mathrm{P}$ & III & Nigeria market & \\
\hline & Tackle & Glyphosate $360 \mathrm{~g} / \mathrm{l}$ & Aminophosphonates glycine & $\mathrm{C}_{3} \mathrm{H}_{8} \mathrm{NO}_{5} \mathrm{P}$ & III & Nigeria market & \\
\hline & Total & Glyphosate $360 \mathrm{~g} / \mathrm{l}$ & Aminophosphonates glycine & $\mathrm{C}_{3} \mathrm{H}_{8} \mathrm{NO}_{5} \mathrm{P}$ & III & Nigeria market & \\
\hline & Force up & $\begin{array}{l}\text { Glyphosate } 360 \mathrm{~g} / 1 \\
\text { Glyphosate isopropryl } \\
\text { ammonium } 480 \mathrm{~g} / 1\end{array}$ & Aminophosphonates glycine & $\mathrm{C}_{3} \mathrm{H}_{8} \mathrm{NO}_{5} \mathrm{P}$ & III & Nigeria market & \\
\hline & Finish & Glyphosate $360 \mathrm{~g} / 1$ & Aminophosphonates glycine & $\mathrm{C}_{3} \mathrm{H}_{8} \mathrm{NO}_{5} \mathrm{P}$ & III & Nigeria market & \\
\hline
\end{tabular}

Ia = Extremely dangerous; Ib = Highly dangerous; II = Moderately hazardous; III = Slightly hazardous; $\mathrm{U}$ = Does not appear to present a hazard under normal conditions of use; O = Pesticide obsolete, unclassified. 
Table 5 Import ant agricultural practices adopted by the study area farmers

\begin{tabular}{|c|c|c|c|c|c|c|}
\hline \multirow[t]{2}{*}{ Variables } & \multirow[t]{2}{*}{ Modalities } & \multicolumn{3}{|c|}{ Percentages } & \multirow{2}{*}{$\begin{array}{c}\text { Chi-Square } \\
\chi_{2}\end{array}$} & \multirow{2}{*}{$\begin{array}{l}\text { Probability } \\
\alpha<0.05\end{array}$} \\
\hline & & Bonou & Ouinhi & Zagnanado & & \\
\hline \multirow[t]{4}{*}{ Fertilizers } & Mineral & 65.4 & 79.2 & 59.0 & \multirow{4}{*}{25.412} & \multirow{4}{*}{0.000} \\
\hline & Organic & 1.30 & 2.50 & 12.0 & & \\
\hline & Mixte & 9.00 & 10.8 & 11.0 & & \\
\hline & No fertilizers & 24.4 & 7.50 & 18.0 & & \\
\hline \multirow[t]{3}{*}{ Management of pests } & Pesticides & 87.2 & 85.7 & 87.0 & \multirow{3}{*}{16.071} & \multirow{3}{*}{0.013} \\
\hline & Aqueous extract & 1.30 & 1.70 & 1.00 & & \\
\hline & Mixed use & 1.30 & 10.9 & 7.00 & & \\
\hline \multirow[t]{3}{*}{ Type of pesticides } & Insecticides + Herbicides & 85.9 & 57.1 & 48.00 & \multirow{3}{*}{99.996} & \multirow{3}{*}{0.000} \\
\hline & Insecticides & 0.00 & 31.1 & 32.0 & & \\
\hline & Herbicides & 14.1 & 8.40 & 14.0 & & \\
\hline \multirow[t]{3}{*}{ Storage of pesticides } & Inside the house & 64.1 & 54.6 & 51.0 & \multirow{3}{*}{27.604} & \multirow{3}{*}{0.000} \\
\hline & Stores & 1.30 & 10.9 & 7.00 & & \\
\hline & In the fields & 14.1 & 30.3 & 35.0 & & \\
\hline \multirow{4}{*}{$\begin{array}{l}\text { Treatment of empty } \\
\text { packaging }\end{array}$} & Recycled / reused & 1.30 & 14.3 & 8.00 & \multirow{4}{*}{1.344} & \multirow{4}{*}{0.000} \\
\hline & Throws & 88.5 & 33.0 & 59.0 & & \\
\hline & Buried & 0.00 & 37.4 & 14.0 & & \\
\hline & Burned & 10.3 & 3.30 & 0.00 & & \\
\hline \multirow[t]{2}{*}{ Spreaders } & Backpack Sprayers & 82.1 & 95.8 & 90.0 & \multirow{2}{*}{11.291} & \multirow{2}{*}{0.023} \\
\hline & Bottles and Branches & 6.40 & 2.50 & 5.00 & & \\
\hline
\end{tabular}

During spraying of chemicals, very fewer producers (less than 10 $\%$ ) use complete recommended protective gears, which are necessary for their protection. Most commonly used protective gears are gloves, boots, goggles, masks and makeshift noses, handkerchiefs, long-sleeved clothing and hats. Among the surveyed farmers, $52.3 \%$ of farmers preferred to use at least one protective gear during spraying while $39.6 \%$ of the producers did not use any protective gear. Some common arguments, used to justify the lack of protection, are the unavailability of equipment in the market, the excessive purchase cost of such equipment, the difficulty of changing clothes after spraying, lack of comfort at work, the wearing of protective equipment deemed unnecessary and negligence.

Some of the respondent's (7.1\%) used, aqueous extract of neem leaves (Azadirachta indica) in addition to chemical pesticides. Very few producers (1\%) used only neem aqueous extracts for the management of the insect pest. The use of the aqueous extract of neem leaves is vulgarized by structures such as Benin National Institute of Agricultural Research (INRAB) and Cowpea Project for Africa (PRONAF).

\subsection{Local perception of farmers regarding the heal th effects of} pesticide inputs

The impacts of pesticides on health are not well perceived by producers. The symptoms commonly observed by farmers during and after field spraying were skin burns, headache, blurred vision, hand shaking, severe coughing, stomach pain (Ranging from simple cramps, nausea to vomiting), respiratory problems, colds, skin irritation, and dizziness. These symptoms are felt by $83 \%$ of the farmers of Zagnanado district, $79.5 \%$ of the Bonou farmers and $92.5 \%$ of the farmers in the district of Ouinhi. To mitigate the effect of these chemicals, farmers used rudimentary methods such as the use of coatings (mentholatum in the nostrils), consumption of leafy decoction, washing the body with soap and consuming milk "Peak" after each treatment.

3.5. Farmers' perceptions regarding the impact of used agricul tural activities on the en vironment

In prepared questionnaire, some question related to the impact of farmer's agricultural activity on the quality of various environmental constitutes, was also incorporated. Among the studied respondents, $57.0 \%$ of the respondents believed that the use of pesticides can be dangerous to humans and environment while $23.0 \%$ of the respondents did not have any opinion on this issue and rest $20.0 \%$ producers believed that they did not face or observed any negative effects on the environment and humans during or after spraying these chemicals. Some of the common impact which was identified by the surveyed area respondents are declining soil fertility, destruction of soil fauna, soil depletion, fish poisoning and mortality, poisoning in animals or human being, the prevalence of diseases related to the use of products, contamination of human food products, water contamination by pesticides, soil erosion, loss of vegetation, filling of streams. Similarly, producers establish a relationship between the risks of contamination of water and fish by pesticides and toxic hazards for humans who consume them. On the other hand, for the soil, the answers are mixed. 
According to them, the use of pesticides would contribute to strengthen and maintain its fertility.

\section{DISC USSION}

\subsection{Agriculture and Cultural practices}

Agricultural practices are considered as the whole process and mode of action of farmers. Thus, they include the technical management of the farm and the management of the cropping system (Pourias, 2014). The cultural practices identified in studied districts (Zagnanado, Bonou and Ouinhi) have generally positive and negative consequences on the environment. In the first stage of the crop cycle, most of the farmers adopted manual cleaning, which preserves useful stumps and trees and don't disturb the root network or the superficial horizons of the soil (Roose, 1985). Slash-and-burn method, which contributes in soil degradation, is widely used. During this, high fumes are released and generate atmospheric pollution (ABE, 2002). According to Bertrand \& Gigou (2000), fire destroys $80-90 \%$ of the plant matter during this practice. Available soil nitrogen is volatilized, and produced ash, is dispersed by wind or runoff, instead of enriching the soil. In addition, fire superficially modified the soil surface which reduced the soil porosity and increase runoff and soil erosion (Serpantié et al., 2001). However, slash-and-burn cultivation can be favorable when it is done in piles with spreading and burial of ashes during plowing (Bertrand \& Gigou, 2000). In the south of Benin Republic, this method has been also identified (Kouelo et al., 2016). Traditional combination or intercropping saving cropping time and help in better labor management during the agricultural season (Kaboré et al., 1995). Further, intercropping not only provide better coverage of the soil surface, but also provide better nutrient supply, especially when they mix a cereal with creeping plants like cowpea. Mix cultivation reduced the risk of parasitic attack, disease and colonization by weeds and also provide protection against the aggressiveness of raindrops which reduced $36 \%$ crop production and lead to a reduction in water, land and nutrient losses by runoff (Maatman \& Schweigman, 1995). Study area farmers are also familiar with the crop rotation which help in reducing parasitic and pest attacks and slows down the mineral and organic fertility loss of soils.

This study revealed higher use of chemical pesticides and fertilizers and the use of organic manure is not widespread among producers of these three districts. Chemicals (fertilizers and pesticides) in most Sub-Saharan African (SSA) countries have negative effects on human health and also on the environment (Kouelo et al., 2016). These results are contradictory with the findings of Bâ et al. (2016) in the Niayes area of Dakar (the Patted'Oie and Malika) Senegal, where organic fertilizers are commonly used by farmers. Sometime, excess uses of organic fertilizers have negative impacts on the ecosystem and sometime beyond the ecosystems. According to Ndiaye (2009), organic manure, especially poultry droppings, has wide spectrum of pathogenic microorganisms and sometime these microorganisms reached up to the ground water table also. As far as inorganic fertilizers are concerned, the main ones used by farmers are NPK and urea. Cissé et al. (2003) and Bâ et al. (2016) reported the use of urea and NPK as a widespread practice across the Niayes in the Dakar region. Use of pesticides and mineral fertilizers can affect the quality of soils by making changes in the physical and chemical properties of the soil (Le Clech, 1998). Indeed, higher uses of mineral fertilizers (NPK) have acidifying effect by the reduction of the organic carbon content in the soil. Two pesticides belonging to WHO classes Ia and Ib are applied to the crops in the study area (Table 4; WHO, 2010). Obopile et al. (2008) and Diop (2013) reported excessive use of pesticides containing active ingredients classified as extremely or highly hazardous in Botswana and the Niayes region of Dakar. This situation can be explained by the weak enforcement capacities of the pesticide regulations in Benin as in most underdeveloped countries. The main cause of this is the lack of human, material and financial resources. The consequences of this non-application of the regulation by the farmers are the presence of informal supply chains, the bulk and unlabeled repackaging of pesticides, the uncontrolled multiplication of phytosanitary products outlets, the presence on the market of counterfeit, sub-dosed or over-dosed products that cause loss of efficacy, insect resistance phenomena and potential risks to human health and the environment, lack of Marketing qualifications of retailers and street sellers, lack of import controls, and cross-border flows from Nigeria and Togo (Matthews et al., 2003).

Most of the surveyed respondents used manual backpack sprayers for the application of phytosanitary products. Similar results were reported in Ghana by Ntow et al. (2006) and in Dakar (Senegal) by Diop (2013). The use of these equipments is also risky because most of the used backpack sprayers have frequent leakage of liquid. In addition, the high cost of sprayers does not favor the replacing of old equipment which is generally poorly maintained. Matthews et al. (2003) reported only 25\% suitable sprayers in Cameroon. Other materials (watering can and plant branches) used for the treatment of pesticides have been also identified by various researchers in Central Africa, Côte d'Ivoire and Togo (Doumbia \& Kwadjo, 2009; Sougnabe et al., 2010 ; Kanda et al., 2013). On the other hand, it was reported that level of protection equipment during spreading is very low. This situation has already been depicted by PAN Togo (2005) and OBEPAB (2006). During spraying, air became polluted and fully loaded with aerosol particles that would be inhaled by the inhabitants near the fields. Dumler et al. (1993), and Guissou et al. (1996) reported higher risk of pesticide poisoning in those cotton producers who had longterm exposure of pesticide contaminate air without adequate protective equipment. According to Kankou (2004) and Gomgnimbou et al. (2009), the lack of personal protective 
equipment increases the risk of poisoning, which can become serious by bioaccumulation.

The study of the pesticide supply routes revealed three circuits, namely the formal one, the local market and the external market. Similarly, Sougnabé et al. (2010) also identified similar three pesticide supply routes in Chad, Cameroon, and the Central African Republic. Official channels for the distribution of pesticides in these three countries are not controlled, hence the proliferation of the informal sector. Four distribution channels have been identified by OBEPAB (2006) in Kobe, Déni and Okéowo in northern Benin. In the Banikoara district, $33 \%$ of producers rely on the informal sector which belongs to Togo, Nigeria, Ghana etc. (Agbohessi et al., 2011). Diop (2013) also showed that $61.5 \%$ of market gardeners in the Niayes district of Senegal were supplied with phytosanitary products from nonapproved retailers.

\subsection{Perceptions of environmental and health impacts among farmers}

Agricultural practices related to phytosanitary treatment, application of fertilizers and the use of agricultural chemical inputs for other purposes have negative impacts on human health. Risk of adverse health effects from pesticide use are often exacerbated in developing countries by poor access to information, farmers' illiteracy and unavailable or unaffordable protective equipment (Maumbe \& Swinton, 2003). During the exposure, the operator feels only minor disturbances, but in the long term, various disease and disturbance may appear (INRS, 2007). Result of study revealed the farmers ignorance toward the environmental and health risks related to the use of the chemical inputs. Some other African researchers also reported farmer's ignorance (Doumbia \& Kwadjo, 2009; Thiam \& Sagna, 2009; Diop, 2013). Further, Sougnabé et al. (2010) and Gomgnimbou et al. (2010) also reported that farmers involved in cotton cultivation in Chad and Burkina Faso did not have a good knowledge of the active ingredients of the pesticides used and their impacts on human health. The symptoms listed by the producers in the study area are skin irritations, headaches and st omach ache. Discomforts such as vomiting and dizziness are also cited by producers as cases that often occur. Similar symptoms were recorded by Adjagodo et al. (2016) in the lower Ouémé valley in Benin Republic, by PAN Togo (2005), OBEPAB (2006), Toé (2007) and Ouattara (2008) in cotton producers of the West African region.

For better management and protection of the environment, humanity developed a new perspective to decrease the negative effects of agriculture which is sustainable agriculture. This allows good agricultural practices, organic agriculture and precision agriculture. Also rotation, sowing of legumes that able to nitrogen fixation reduces the negative effect of agriculture on environment. Farmers must turn to agricultural techniques for soil conservation, pest management that can preserve their health, and environment.
It is necessary to find alternative solutions to limit the use of chemical inputs.

\section{Conclusion}

Through this study, the elements to be retained are that farmer's practices such as the use of organic fertilizers, crop rotation, fallow, preventive pest control and ecological control are observed in studied districts. However, the adoption rate of these practices is very low. In the studied districts, agricultural activities are more degrading than conserving environment. The lack of sustainable strategies for strengthening production (soil amendment, agroforestry, etc.) and the lack of perception of environmental risks, linked to agricultural intensification, are points to be considered in the development plans, in order to allow a better integration of all agricultural activities in the study area. New crop management systems capable to reduce reliance on pesticides, such as aqueous extracts and biopesticide, should be promoted. Integrated crop management, well understood and properly applied, can contribute to good results with minimal impact on the environment. Its implementation requires the intensification of sensitization. Experimental protocols should be developed to study some environmental compartments that could suffer from agricultural damage.

Conflict of interest

Authors would like to declare that there is no conflict of interests that could possibly arise.

\section{References}

ABE (Agence Béninoise de l'Environnent) (2002) Rapport intégré sur l'Etat de l'environnement au Bénin, Cotonou, Bénin, 187p

Adjagodo A, Agassounou DTM, Kelome NC, Mensah GA, Agbossou E (2016) Gestion des produits phytosanitaires et impacts sur l'environnement et la santé des populations de la basse vallée de l'Ouémé. Actes du Colloque en hommage au Professe ur Fulgence AFOUDA, du 27 - 30 Septembre 2016, Université d'A bomey-Calavi, Ben in $2: 14-24$

Agbohessi PT, Toko II, Yabi JA, Dasso un do-Assogba JF, Kestemont P (2011) Caractérisation des pesticides chimiques utilisés en production cotonnière et impact sur les indicateurs économiques dans la Commune de Banikoara au nord du Bénin. International Journal of Biological and Chemical $\begin{array}{llll}\text { Sciences } & 5: & 1828-1841 . & \text { DOI : }\end{array}$ http://dx. doi.org/10.4314/ijbcs.v5i5.6.

Ba A, Cantoreggi N, Simos J, Duchemin E (2016) Impacts sur la santé des pratiques des agriculteurs urbains à Dakar (Sénégal), VertigO, la revue électronique en sciences de l'environnement $16: 1-16$. 
Bertrand R, Gigou J (2000) La fertilité des sols tropicaux. Maisonneuve et Larose, France.

Cissé I, Tandia AA, Fall ST et Diop EHS (2003) Usage incontrôlé des pesticides en agriculture périurbaine : cas de la zone des Niayes au Sénégal. Cahiers Agricultures 12 : 181-186.

Dagnelie P (1998) Statistique théorique et appliquée. Tome 2: Inférences statistiques à une et deux dimensions. De Boeck et Larcier, Paris-Bruxelles, Belgique, France.

Diop A (2013) Diagnostic des pratiques d'utilisation et quantification des pesticides dans la zone des Niayes de Dakar (Senegal). Doct oral thesis submitted to University of Littoral Côte d'Opale. (Sénégal), Pp. 240.

Dümler C, Schwab A, Jäger-Mischke I, Thiam A, Stoll G, Görgen R, Prexler-Schwab S (1993) Pesticides et Agriculture Tropicale : Dangers et Alternative, PAN-CT A, Weikersheim, Pp. 281.

Doumbia M, Kwadjo KE (2009) Pratiques d'utilisation et de gestion des pesticides par les maraîchers en Côte d'Ivoire: Cas de la ville d'Abidjan et deux de ses banlieues (Dabou et Anyama). Journal of Applied Biosciences 18: 992 - 1002 .

Gomgnimbou APK, Savadogo PW, Nianogo AJ, MillogoRasolodimby J (2009) Usage des intrants chimiques dans un agrosystème tropical: diagnostic du risque de pollution environnementale dans la région cotonnière de l'est du Burkina Faso. Biotechnology, Agronomy, Society and Environment 13 : 499-507.

Gomgnimbou A, Savadogo P, Nianogo A, Millogo-Rasolodimby J (2010) Pratiques agricoles et perceptions paysannes des impacts environnementaux de la cotonculture dans la province de la KOMPIENGA (Burkina Faso). Sciences \& Nature $7: 65-175$.

Guissou, IP, Toe, MA, Domo, Y, Hema, OS (1996) Contribution à la toxicologie agro-alimentaire au Burkina Faso: épidémiologie des intoxications aux pesticides et activités cholinestérasiques sériques chez les producteurs de la zone cotonnière de la boucle du Mouhoun. Études Recherches 4 : 39-48.

Hauchart V (2007) Durabilité de l'agriculture en fonction des pratiques culturales actuelles et conseillées (Burkina Faso et Nord Ghana). Volta Basin Focal Project Report $N^{\circ} 2$. IRD, Montpellier, France, and CPWF, Colombo, Sri Lanka, Pp. 109.

INRS (2007) Utilisation des produits phytosanitaires en agriculture tropicale. Instit ut National de Recherche et de Sécurité, Paris.

INSAE (Institut National de la statistique et de l'analyse économique du Bénin) (2015) Recensement National de la population RGPH4. Pp. 20.
Kaboré D, Kambou F, Dickey J, Lowenberg-De Boer J (1995) Economie des cordons pierreux, du paillage et du zai dans le nord du Plateau Central du Burkina Faso: une perspective préliminaire, 1990-1994.

Kanda M, Djaneye-Boundjou G, Wala K, Gnandi K, Batawila K, Sanni A, Akpagana K (2013) Application des pesticides en agriculture maraichère au Togo ", Vertigo - la revue électronique en sciences de l'environnement $13: 1-17$. DOI : 10.4000 /vertigo. 13456 .

Kankou MOS (2004) Vulnérabilité des eaux et des sols de la rive droite du fleuve Sénégal en Mauritanie : Etude en laboratoire du comportement de deux pesticides, Doctoral Dissertation submitted to University of Limoges, France, Pp. 159.

Koudokpon V, Brouwers J, Versteeg MN, Budelman A (1994) Priority setting in research for sustainable land use: The case of the Adja Plateau, Bénin. Agroforestry System 26: 101-122. doi:10.1007/BF00707009.

Kouelo FA, Houngnandan P, Dedehouanou H, Tossou R, Bello DO, Kossobakan J, Bekou A, Tchetangni AY (2016) Soil conservation practices in three watersheds of Benin: Farmers' cropping systems characterization. African Journal of Agricultural Research 11 : 507-515. DOI: 10.5897/AJAR2015.10277.

Le Clech B (1998) Agriculture et environnement. Synthèseagricole, Paris, France.

Maumbe BM, Swinton SM (2003) Hidden health costs of pesticide use in Zimbabwe's smallholder cotton growers. Social Science \& Medicine 57: 1559-1571. DOI: https://doi.org/10.1016/S02779536(03)00016-9.

Maatman A, Schweigman C (1995) A study of farming systems on the Central Plateau in Burkina Faso: application of linear programming, ASP/SADAOC project.

Matthews G, Wiles T, Baleguel P (2003) A survey of pesticide application in Cameroon. Crop Protection 22: 707-714. DOI : https://doi.org/10.1016/S0261-2194(03)00008-5.

Ndiaye ML (2009) Impacts sanitaires des eaux d'arrosage de l'agriculture urbaine de Dakar (Sénégal), Thèse de doctorat, Faculté des sciences de l'université de Genève, Pp. 100.

OBEPAB (Organisation Béninoise pour la Promotion de l'Agriculture Biologique) (2006) Identification des problèmes sanitaires et environnementaux liés aux Pops. Rapport d'étude, IPEP, Cotonou, Benin.

Obopile M, MunthalI DC, Matilo B, (2008) Farmers' knowledge, perceptions and management of vegetable pests and diseases in 
Botswana. Crop Protection 27: 1220-1224 https://doi.org/10.1016/j.cropro.2008.03.003.

Ouattara A (2008) Des pesticides qui tuent leurs utilisateurs. Available on http://ipsinternational.org/fr/_note.asp?idnew/ access on $29^{\text {th }}$ April, 2016.

PAN TOGO (Pesticide Action Network Togo) (2005) Étude d'impact socio-économique, sanitaire et environnemental de l'utilisation des POPs à Davié au Nord de Lomé (région Maritime). Togo. Rapport d'étude, Lomé, IPEP, PAN Togo,Pp. 37.

Pourias J (2014) Production alimentaire et pratiques culturales en agriculture urbaine: analyse agronomique de la fonction alimentaire des jardins associatifs urbains à Paris et Montréal, Doctoral dissertation, Université du Québec à Mont réal.

Roose E (1985) Terrasses de diversion ou microbarrages perméables :Analyse de leur efficacité en milieu paysan ouestafricain pour la conservation de l'eau et des sols dans la zone soudano-sahélienne, Ive Conférence Internationale DeConservationdes Sols. ISCO, Maracay(Venezuela)39novembre1985,Pp. 15.

Serpantié G, Ouattara B, Louppe D, SougafaraB, Gnahoua GM, Ouattara N, Mallet B (2001) Fertilité et jachères en Afrique de l'Ouest. Floret C. et Pontanier R., La jachère en Afrique tropicale $2: 21-84$.

Shujaat AK, ArshadA, Muhammad NB (2013) The Linkage between Agricultural Practices and Environmental Degradation. Journal of Environmental Treatment Techniques 1: 19-22.

Soule B (2012) Politique agricole de la CEDEAO : la monographie du Bénin. Cotonou, Bénin Pp. 24.

Sougnabe SP, Yandia A, Acheleke J, Brevault T, Vaissayre M, Ngartoubam LT (2010) Pratiques phytosanitaires paysannes dans les savanes d'Afrique centrale, Actes du colloque «Savanes africaines en développement : innover pour durer », Garoua, Cameroun, Cirad, Montpellier, France, 1-13.

Soclo H (2003) Étude de l'impact de l'utilisation des en grais chimiques et des pesticides par les populations riveraines sur les écosystèmes (eaux de surface, substrat des réserves de faune) dans les complex es des aires protégées de la Pendjari et du W. Rapport d'étudedu CENAGREF, Cotonou, Bénin. http:// www.cenagref.net access on $29^{\text {th }}$ April, 2016.

Thiam A, Sagna MB (2009) Monitoring des pesticides au niveau des communautés à la base. Rapport Régional Afrique, Dakar, Sénégal, Pesticide Action Net work Africa.

Toé MA (2007) Utilisation des pesticides chimiques en cult ures marâichères et cotonnières dan $\mathrm{s}$ la région Est du Burkina Faso, Campagne 2005-2006 et 2006-2007, Rapport d'étude, IRSS, Bobo Dioulasso, Burkina Faso.

Ntow WJ, Gijzen HJ, Kelderman P, Drechsel P (2006) Farmer perceptions and pesticide use practices in vegetable production in Ghana. Pest Management Science 62: 356-365. DOI: $10.1002 /$ ps.1178

WHO (World Health Organization) (2010) The WHO Recommended Classification of Pesticides by Hazard and Guidelines to Classification. WHO Press, World Health Organization, Wissenchaftliche Verlagsgesellschaft $\mathrm{mbH}$, St ut tgart, Germany. 81

Yehouenou APE, Glin LC, Vodouhe DS, Fanou J, Babadankpodji AP, Dassou S, Vodouhe S, van Hattum B, Swart K, van Gestel CAM (2014) Pesticide contamination of the dridji cotton plantation area in the republic of Benin. African Journal of Food and Agric ult ure 14: 8886-8902. 